\title{
Case Report: Post Kala-Azar Dermal Leishmaniasis with History of Visceral Leishmaniasis
}

\author{
Pavankumar Narapaka ${ }^{1}$, Kalpana Katikala ${ }^{2}$ \\ ${ }^{1,2}$ M Pharmacy, Department of Pharmacy Practice, National Institute of Pharmaceutical Education and Research, \\ Export Promotion Industrial Park (EPIP), Zandhaha Road, NH 322, Hajipur, Bihar - 844102
}

Corresponding Author: Pavankumar Narapaka

\begin{abstract}
The complication of visceral leishmaniasis is post-kala-azar dermal leishmaniasis (PKDL). PKDL typically occurs as a result of treatment failure or parasite resistance to treatment regimens, as well as poor patient follow-up. In the treatment of visceral leishmaniasis and postkala-azar dermal leishmaniasis, Liposomal Amphotericin B is considering as first-line therapy. We're going to show you a case where Liposomal Amphotericin B was used to treat it.
\end{abstract}

Keywords: visceral leishmaniasis, post-kala-azar dermal leishmaniasis, PKDL, kala-azar

\section{INTRODUCTION}

$$
\text { Post-Kala azar Dermal }
$$

Leishmaniasis (PKDL) is a visceral Leishmaniasis complication that appears as a macular, papular, or nodular rash on the forehead, upper arms, trunks, and other body parts and spread to other parts of the body depending on severity. Generally, PKDL can observe in India and Sudan with the causative organism Leishmania donovani parasite, which follows $50 \%$ of VL and $5-10 \%$ of PKDL cases. The interval of PKDL follows VL 2-3 years in India and 0-6 months in Sudan. Leishmania parasite transmits through the bite of the infected female phlebotomine sandfly, it Injects the infective stage (promastigotes) into the host body, considered as anthroponotic with humans as the only known infection reservoir. ${ }^{[1]}$ PKDL characterized by the spread of skin lesions, hypopigmentation of macule, papules, nodules, over the trunk, and face could be is easily confused with different diseases such as vitiligo and leprosy. ${ }^{[2]}$ Only 21 known species are the cause of a disease out of 54 species known in many countries, and 350 million are at risk of this infection. ${ }^{[3]}$

\section{CASE}

A 25 years female suffering from maculopapular, nodular lesions on the face and upper limbs for one month. She first noticed lesions on the chin, which spread to parts of the face and upper limbs. After a lesion appears on the face patient went to a local health care provider, he had referred to a tertiary hospital. She stated a history of visceral leishmaniasis, No family history of leishmaniasis, and other diseases. The patient had no history of smoking and alcohol consumption. After the physical examination, no abnormalities were found other than skin lesions, and lesions were non-itching.

\begin{tabular}{|l|l|}
\hline Patient history & $\begin{array}{l}\text { she had a history of VL treated with sodium } \\
\text { stibogluconate. }\end{array}$ \\
\hline Family history & $\begin{array}{l}\text { No family history of leishmaniasis and other } \\
\text { diseases }\end{array}$ \\
\hline Social history & $\begin{array}{l}\text { The patient does not have any social history } \\
\text { of smoking and alcohol consumption }\end{array}$ \\
\hline $\begin{array}{l}\text { Physical } \\
\text { Examinations }\end{array}$ & $\begin{array}{l}\text { On the physical examination, no } \\
\text { abnormalities were found other than skin } \\
\text { lesions, lesions were no itching. }\end{array}$ \\
\hline Clinical & $\begin{array}{l}\text { rK 39 } \\
\text { Skin biopsy } \\
\text { Complete Blood Count } \\
\text { HBsAg } \\
\text { HCV Antibodies } \\
\text { HIV(rapid test) }\end{array}$ \\
\hline
\end{tabular}


Pavankumar Narapaka et.al. Case report: post kala-azar dermal leishmaniasis with history of visceral leishmaniasis.

The patient was positive for the rk39 test; Skin samples were collected and send to the laboratory for biopsy. The patient was positive for Leishmania donovani in the biopsy, patients recommended for CBC, HBsAg, HCV antibodies, HIV test, the patients found to be negative for HBsAg, HCV antibodies test, HIV test.

\section{HEMATOLOGICAL \& BIOCHEMICAL INVESTIGATIONS:}

Hematological reports revealed a total Red Blood Cell (RBC) of 4.24 Million cells/mcL, total White Blood Cells (WBC) of 2700 cells/microL with Neutrophils $66 \%$, Lymphocytes 22\%, Monocytes 7\%, and Eosinophils 5\%, Basophiles 0\%, Platelet 3,43,000 cells/ microlitre Biochemical reports revealed total protein $6.80 \mathrm{~g} / \mathrm{dl}$, Albumin 3.62g/dl, Globulin 3.18g/dl, Serum $1 \mathrm{mg} / \mathrm{dl}$, Blood urea $20.6 \mathrm{mg} / \mathrm{dl}$, Serum creatinine $0.6 \mathrm{mg} / \mathrm{dl}$, SGOT/ASAT 38.9
U/L， SGPT/ALAT $32.0 \quad$ U/L, Alkaline Phosphate 132/7 U/L. HBsAg 0.050, HCV antibodies 0.036

\section{Hematology report}

\begin{tabular}{|l|l|l|}
\hline Test & Results & Reference range \\
\hline Total protein & 6.80 & $6-8.3 \mathrm{~g} / \mathrm{dl}$ \\
\hline Albumin & 3.62 & $3.2-5.5 \mathrm{~g} / \mathrm{dl}$ \\
\hline Globulin & 3.18 & $2.8-3.0 \mathrm{~g} / \mathrm{dl}$ \\
\hline Serum bilirubin & 1.00 & $\mathrm{Up}$ to $1.10 \mathrm{mg} / \mathrm{dl}$ \\
\hline Blood urea & 20.6 & $15-45 \mathrm{mg} / \mathrm{dl}$ \\
\hline Serum creatinine & 0.6 & $0.6-1.1 \mathrm{mg} / \mathrm{dl}$ \\
\hline SGOT & 38.9 & $\mathrm{Up}$ to $34 \mathrm{u} / 1$ \\
\hline SGPT & 32.0 & $\mathrm{Up}$ to $35 \mathrm{u} / 1$ \\
\hline Alkaline phosphatase & 132.7 & $98-279 \mathrm{u} / 1$ \\
\hline HBsAg & 0.050 & \\
\hline HCV Antibody & 0.036 & \\
\hline
\end{tabular}

\section{Biochemical Report}

\begin{tabular}{|l|l|l|}
\hline Test & Result & Reference range \\
\hline Total RBC & 4.24 & $4.2-5.4$ million cells/mcL \\
\hline Total WBC & 2700 & $4500-11000$ cells/ micro L \\
\hline Neutrophils & 66 & $40-80 \%$ \\
\hline Lymphocytes & 22 & $20-40 \%$ \\
\hline Monocytes & 07 & $2-10 \%$ \\
\hline Eosinophils & 05 & $1-6 \%$ \\
\hline Basophils & 00 & $0-1 \%$ \\
\hline Platelets & 3.43 & $150000-450000$ cells/ MCL \\
\hline Hemoglobin & 13.7 & $12-15.5$ gm/dl \\
\hline
\end{tabular}

TREATMENT PLAN:

\begin{tabular}{|c|c|c|c|c|c|}
\hline ROA & DRUGS & DOSE & FREQUENCY & $\begin{array}{ll}\text { DATE } & \text { OF } \\
\text { START } & \\
\end{array}$ & $\begin{array}{l}\text { DATE OF } \\
\text { END }\end{array}$ \\
\hline IV & Ambisome(liposomal Amphotericin B) & $\begin{array}{l}265 \mathrm{mg}-6 \\
\text { doses }\end{array}$ & $\begin{array}{l}\text { Single-dose with } 4 \text { days of } \\
\text { interval }(265 \mathrm{mg})\end{array}$ & $30 / 01 / 2020$ & $19 / 02 / 2020$ \\
\hline Oral & $\begin{array}{l}\text { Ferimon(ferric ammonium citrate, folic acid, } \\
\text { and cyanocobalamin) }\end{array}$ & $5 \mathrm{ml}$ & BID & $30 / 01 / 2020$ & $19 / 02 / 2020$ \\
\hline Oral & Becogen L & $5 \mathrm{ml}$ & $\mathrm{BID}$ & $30 / 01 / 2020$ & $19 / 02 / 2020$ \\
\hline Oral & Paracetamol & $500 \mathrm{mg}$ & SOS & $30 / 01 / 2020$ & $19 / 02 / 2020$ \\
\hline Oral & B-complex( Vit-B1, B2, B3, B5, B6,B12) & $5 \mathrm{ml}$ & BID & $30 / 01 / 2020$ & $19 / 02 / 2020$ \\
\hline Oral & Albendazole & $400 \mathrm{mg}$ & HS & $03 / 02 / 2020$ & $05 / 02 / 2020$ \\
\hline
\end{tabular}

\section{AMBISOME (Liposomal Amphotericin B) Administration Chart: Amphotericin B-265mg with 5\% D/W in 6 doses}

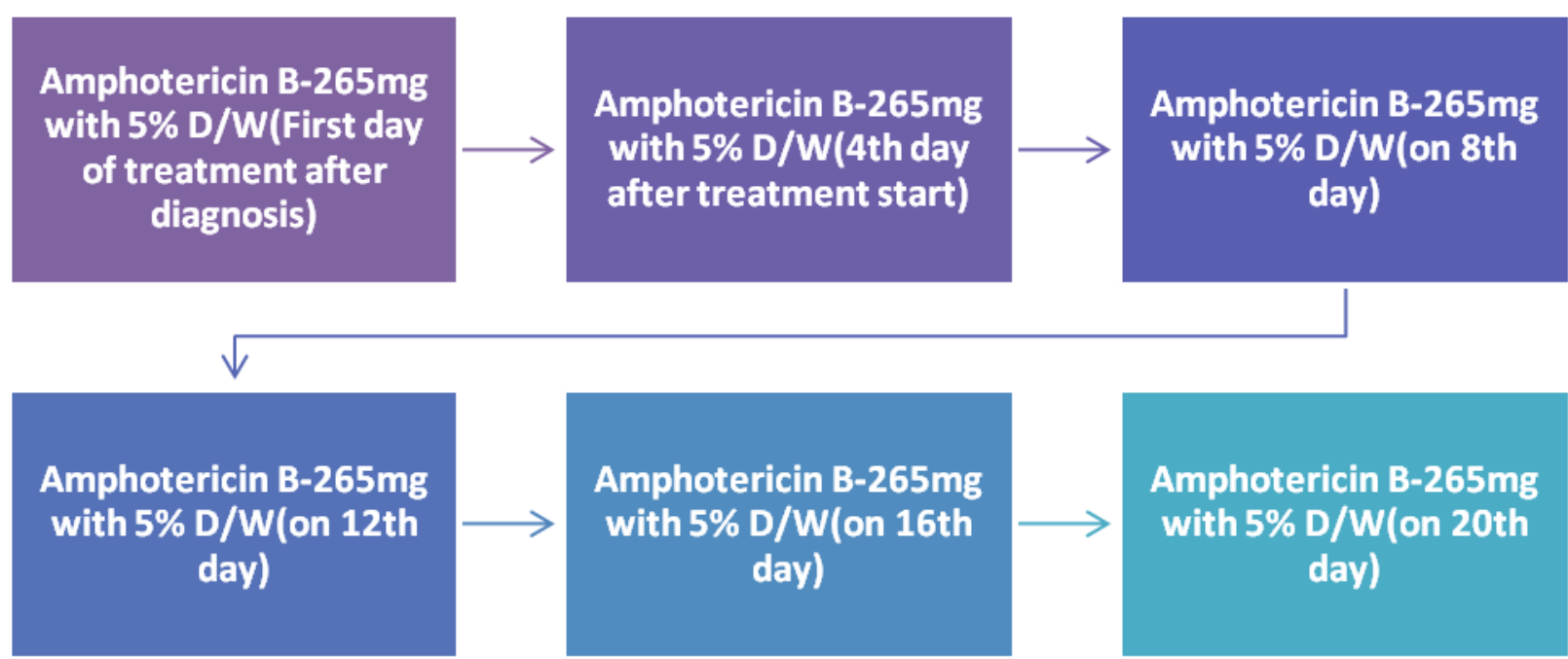




\section{DRUG INTERACTIONS IN PRESCRIPTION:}

- There are no severe drug interactions in this prescription

- ferimon syrup may interact with acetaminophen/paracetamol physician is giving paracetamol when it is required there is no drug interaction between these two regimens

- There is no drug interaction between albendazole and other drugs in this prescription.

- Vitamin b complex generally interacts with an antibiotic (chloramphenicol), anti-cancer drug (cisplatin), and seizures drug (phenytoin), no such type of drugs here.

- No drug interaction between paracetamol and other drugs in prescription.

- Amphotericin does not show any drug interaction with these prescription drugs.

\section{CONTRA-INDICATIONS:}

- There are no such severe contraindications in these prescription drugs.

- Vitamin b complex is not suitable for patients with anemia (pernicious anemia). Leishmania patients who have normal anemia are no contraindication of vitamin b complex.

- Paracetamol and ferimon syrup show hypersensitivity reactions in some patients.

\section{SIDE EFFECTS:}

- Nausea, vomiting, stomach upset, diarrhea are common side effects with ambisome, ferimon, b complex

\section{PHARMACIST INTERVENTIONS:}

- Ferimon have interaction with alcohol give proper counseling regarding the medication usage and its interactions

- Counseling patients regarding medication usage and common side effects associated with medication and complications of PKDL
- Some of the side effects associated with the prescription drugs are Nausea, vomiting, stomach upset, diarrhea are common side effects with ambisome, ferimon, b complex, create awareness to the patients on common side effects

- Always be familiar, give confidence to patients suggest them some lifestyle changes during medications and after completion of therapy to avoid PKDL complications

\section{DISCUSSION}

Patients with visceral leishmaniasis who had previously cure with sodium stibogluconate (SSB) developed resistance. Maybe this the cause of post-kala-azar dermal leishmaniasis. Some post-kala-azar dermal leishmaniasis patients had no prior history of visceral leishmaniasis. Patients with Post Kala-azar Dermal Leishmaniasis (PKDL) should be treated with (i) Liposomal amphotericin B: $5 \mathrm{mg} / \mathrm{kg}$ per day by infusion two days per week for three weeks for a total dose of $30 \mathrm{mg} / \mathrm{kg}$, or (ii) Liposomal amphotericin B: $5 \mathrm{mg} / \mathrm{kg}$ per day by infusion two times per week for three weeks for a total dose of $30 \mathrm{mg} / \mathrm{kg}$, or (ii) Meltifosine: $100 \mathrm{mg}$ orally per day for 12 weeks; (iii) Amphotericin B deoxycholate: 1 $\mathrm{mg} / \mathrm{kg}$ for four months in 60-80 doses. ${ }^{[7]}$ There infusion-related side effects managed with paracetamol, pantoprazole, or domperidone on an SOS basis. Throughout the therapy, temperature, pulse, respiration rate, blood pressure tracked regularly, the health-seeking activity observed. It may be contributing factor for disease spread ${ }^{[8]}$.

\section{Acknowledgement: None}

Conflict of Interest: None

\section{Source of Funding: None}

\section{REFERENCES}

1. Zijlstra EE, Musa AM, Khalil EA, El Hassan IM, El-Hassan AM. Post-kala-azar dermal leishmaniasis. The Lancet infectious diseases. 2003 Feb 1;3(2):87-98. 
Pavankumar Narapaka et.al. Case report: post kala-azar dermal leishmaniasis with history of visceral leishmaniasis.

2. Islam QT, Basher A. Atypical presentation of post-kala-azar dermal leishmaniasis. The Lancet Infectious Diseases. 2017 Nov 1;17(11):1218.

3. Desjeux P, Ramesh V. Post-kala-azar dermal leishmaniasis: facing the challenge of eliminating kala-azar from South Asia. InKala Azar in South Asia 2011 (pp. 111124). Springer, Dordrecht.

4. Trindade MA, da Cruz Silva LL, Braz LM, Amato VS, Naafs B, Sotto MN. Post-kalaazar dermal leishmaniasis and leprosy: case report and literature review. BMC infectious diseases. 2015 Dec;15(1):1-8.

5. Gedda MR, Singh B, Kumar D, Singh AK, Madhukar P, Upadhyay S, Singh OP, Sundar S. Post kala-azar dermal leishmaniasis: A threat to elimination program. PLoS Neglected Tropical Diseases. 2020 Jul 2;14(7):e0008221.

6. Hasnain MG, Shomik MS, Ghosh P, Rashid MO, Hossain MS, Hamano S, Mondal D.
Post-kala-azar dermal leishmaniasis without previous history of visceral leishmaniasis. The American journal of tropical medicine and hygiene. 2016 Dec 7;95(6):1383-5.

7. National vector born disease control program. National health mission govt of India. Available online. https://nvbdcp.gov.in/. accessed on (21/03/2021)

8. Garapati P, Pal B, Siddiqui NA, Bimal S, Das P, Murti K, Pandey K. Knowledge, stigma, health-seeking behavior and its determinants among patients with post-kalaazar dermal leishmaniasis, Bihar, India. PloS one. 2018 Sep 7;13(9):e0203407.

How to cite this article: Narapaka P, Katikala K. Case report: post kala-azar dermal leishmaniasis with history of visceral leishmaniasis. International Journal of Research and Review. 2021; 8(5): 69-72. DOI: https://doi.org/ 10.52403/ijrr.20210510 